\title{
Obituaries
}

\section{Ilsley Ingram}

Researcher and clinician who led the development of specialist centres caring for people with haemophilia

Ilsley Ingram combined academic and clinical excellence with erudition in plant taxonomy and the art of a poet. Born in India of missionary parents, he was soon returned to the care of relatives in England after the early death of his sister. Despite an isolated upbringing, he grew up with an unusual sympathy for children and a notable talent for mimicry. He overcame a prominent stammer by developing a gift for reciting verse, sometimes his own.

At Trinity College, Cambridge, Ilsley joined the debating society to help control his stammer. He moved to St Thomas's Hospital, London, in 1941 soon after the Blitzwith most of the medical school then transferring out to Hydestyle in Surrey for the rest of the second world war. $\mathrm{He}$ developed his talent for poetry, but never for music (he was "tone deaf" and later reported writing one of his best papers during a performance of Handel's Messiah). He also learnt hypnotism, and demonstrated this once by getting a fellow student who knew little French to quote a French sonnet fluently and at length.

He was diagnosed as having tuberculosis at the age of 5 ; this was to recur at intervals and disrupted his medical studies. A recurrence soon after he qualified involved his larynx and he had to be mute for a time-clicking for yes and hissing for no. Recovering, he got a post as locum physician at the British Sanatorium for TB

\section{Advice}

We will be pleased to receive obituary notices of around 250 words. Pressure on space means that in most cases we will be able to publish only about 100 words in the printed journal, but we can run a fuller version on our website. We will take responsibility for shortening. We do not send proofs. Good quality, original photographs are welcome. Please give a contact telephone number and, where possible, supply the obituary on a disk or by email to obituaries@bmj.com We need to know the year of birth and exact date of death of the deceased, and we prefer obituaries to state the cause of death. Please spell out abbreviations.

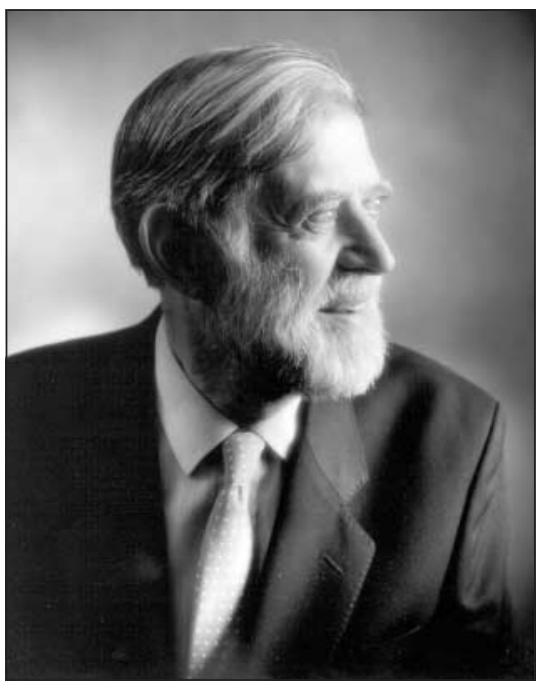

in Switzerland, where he met his wife, a Nightingale ward sister

His MD thesis was on the clinical use of penicillin and was followed by a Wilkie research fellowship under Macfarlane and Biggs in Oxford, and then serendipitously by research into thrombosis with Learmonth in Edinburgh. His discovery, that the infusion of adrenaline raised serum factor VIII levels, presaged the clinical use of desmopressin acetate (DDAVP) in the treatment of haemophilia, as well as in other bleeding disorders such as that associated with renal failure.

In 1960-1 he was a Wellcome Research travelling fellow at Chapel Hill, University of North Carolina, where further work on the factor VIII pathway subsequently led to his appointment to a chair of experimental haematology back in London. In 1963 he was a founder member of the Royal College of Pathologists. He pioneered the concepts of haemophilia centres and of home care for people with haemophilia trained to inject themselves. He was one of the first to allow a patient with inhibitor to factor VIII to store batches of factor VIII inhibitor bypassing fraction (FEIBA) at home in order to treat the bleeds that had now become untreatable with conventional factor VIII preparations.
In this he anticipated the current use of recombinant factor VIIa for such patients. His clinical experience provided the foundation for the influential textbook, co-authored with his friend and colleague Roger Hardisty, Bleeding Disorders: Investigation and Management, published in 1965 and updated in 1982.

Ilsley Ingram was one of the only teachers at St Thomas's to gain applause for his lectures, combining elegant lucidity with being approachable. His laboratory was full of Heath Robinson style devices which, however, worked; though what the modern Health and Safety Executive would have had to say bears little thought.

From an early evangelical Christian focus, his religious faith evolved into a broad humanism, a response perhaps to his active clinical work with haemophiliac patients.

The early years of his retirement were clouded by the tragedy of HIV/AIDS affecting so many of his haemophiliac patients. He worked hard during this time with the Haemophilia Society, of which he was a vice president, eventually helping to persuade the John Major government to provide compensation.

He became warden of Yocklett Bank Nature Reserve near his home in Kent, where he studied ground beetles, as well as continuing his study of orchids, for which he was made a fellow of the Linnaean Society. Throughout his life he wrote poetry; a selection, Four Score, was published in 2002 by Fledgling Press.

During his last years he was disabled by mononeuritis multiplex, which confined him to a wheelchair. He died from bladder cancer in Oxford, leaving his body to anatomical science.

He leaves a wife, Pat; three children; and six grandchildren. [DAVID BENNETT-JONES, George Freeman]

George Ilsley Charlton Ingram, consultant haematologist and professor of experimental haematology St Thomas's Hospital and Medical School, London, 1956-79 (b Naini Tal, India, 1919; q Cambridge/St Thomas's Hospital, London, 1944; MD, FRCP, FRCPath, FLS), d 12 April 2004. 


\section{Patrick Lim Lian Chow Ah-fat}

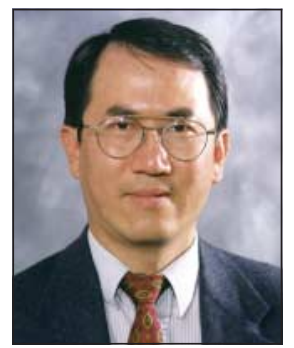

Consultant radiologist Dewsbury District Hospital (b Mauritius 1953; q Manchester 1978; MRCP, FRCR), died from plasma cell leukaemia on 8 July 2003.

Patrick came to England to begin his medical studies in 1973. Soon after his appointment to Dewsbury he took up the mantle of postgraduate tutor. During his tenure he oversaw the transformation of the postgraduate centre to a high standard medical education centre. He was a skilled interventional radiologist and had a great interest and expertise in osteo-articular radiology. He approached his fatal illness with an academic curiosity and worked to support his overstretched department, as far as his illness would allow, right to the end. He leaves a wife and two daughters. [P D Angus]

\section{Philip William Bowden}

Former general practitioner Ashbourne, Derbyshire (b 1926; q London 1949), d 1 May 2004.

After hospital posts in the London area Philip went into general practice near Ashbourne, Derbyshire. For many years he was singlehanded but was able to build the practice up and eventually took in partners. He became a GP trainer. He was also a part time clinical assistant at Derby Children's Hospital and the Pastures Hospital. He had cardiac bypass surgery in 1983 but continued in practice until he retired in 1987, when he was able to pursue his passion for breeding shire horses. He leaves a wife, Rita; three children; and seven grandchildren. [E A Foreman]

\section{Stewart Michael Brydon}

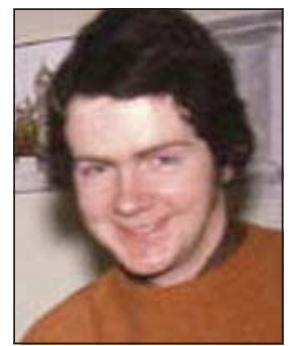

General practitioner Stornoway (b Kelso 1957; $q$ Edinburgh 1982; BSc), d 26 March 2004.

Stewart took up his first partnership in Benbecula, in the Western Isles, and moved to Stornoway in 1992. He made a major contribution to health care in the islands through his service on the health board, helping visiting consultants in respiratory medicine, and pioneering a personal medical services contract for his practice. He developed a model for reorganising out-ofhours care on Lewis. Stewart had a keen interest in immediate care, providing care to the Benbecula army base and serving with the coastguard helicopter in Stornoway. He combined this interest with a lifelong enthusiasm for cars by providing medical services to motor sport. His later years were marred by depression, and he took his own life. He leaves a wife, Diana, and her three children. [JOHN HARrington, JOHN JOHNSTON, Stewart Cherry, Mike Higgins]

\section{Ieuan Lynn Richard Evans}

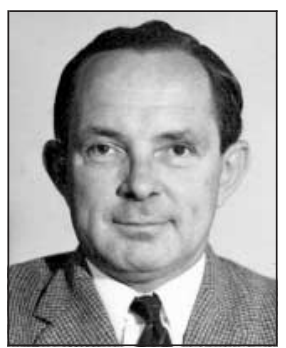

Former general practitioner Rhymney, Gwent (b Bihar, India, 191 7; $q$ Cardiff 1940; $M B E$, JP), d 22 November 2003.

At the end of the second world war Ieuan returned from active service in Burma with obstetrics in mind, but he found the challenge of practice in the South Wales valleys absorbing and contributed for 46 years until 1991 His work included surgery at Redwood Memorial Hospital. He supported the St John Ambulance and the Burma Association, and was a magistrate. Eleven years before he died he had a cerebellar stroke after an operation Predeceased by his wife, Gwyneth, he leaves four children and seven grandchildren. [R I Evans, R W Evans]

\section{Hugh Kelson Ford}

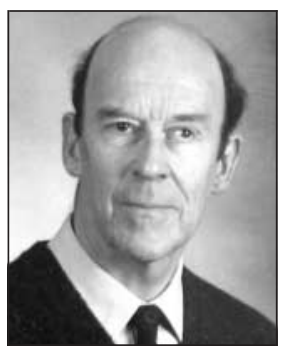

Former general practitioner Heacham, Norfolk (b 1929; $q$ The London Hospital 1951; CVO, DObst RCOG, FRCGP), died from a ruptured thoracic aortic aneurysm on 23 February 2004. After serving as a naval officer Hugh joined a rural Norfolk practice, where he was senior partner for most of his 33 years in practice. He was appointed apothecary to the royal household at Sandringham, a post he held for 23 years. He was deeply involved in medical education and helped start the local vocational training scheme. An early member of the Royal College of General Practitioners, he became provost of the East Anglian faculty. His interest in palliative care culminated in his founding the local hospice in 1984. He served as church warden and became a bishop's selector, helping to select candidates to enter the ministry. He leaves his second wife, Valerie; four children; and six grandchildren. [IAN CAMPBELL]

\section{Richard Charles Harrington}

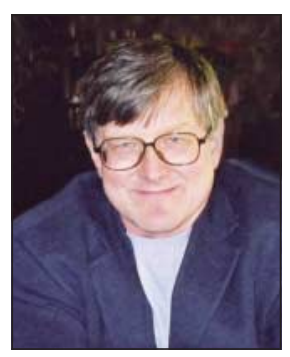

Professor of child and adolescent psychiatry University of Manchester (b 1956;

$q$ Birmingham 1980), died from postoperative complications on 22 May 2004.

Richard Harrington studied psychiatry at the Maudsley Hospital, London, before taking a research post at the Institute of Psychiatry, where he began his studies of children and adolescents with depressive illness. After two years as senior lecturer in Birmingham he was appointed professor of child and adolescent psychiatry at Manchester University. He became chairman of the British Child Psychiatry Research Society and vice president of the European Society of Child and Adolescent Psychiatry. In 1998 the American Academy of Child and Adolescent Psychiatry presented him with an award for best original research in the field of depression in young people. $\mathrm{He}$ leaves a wife, Lesley, and three children. [IAN Goodyear, Alistair Burns]

\section{$\mathrm{p}+$}

\section{Max Hillel}

Former general practitioner Dukinfield, Cheshire (b Baghdad 1917; $q$ The London Hospital 1945), died from aortic value disease on 4 April 2004.

Max came to England in 1934 to study English before entering The London Hospital Medical College. Wartime studies involved many nights of firewatch duty on the hospital's roof. After house jobs he started work at Scunthorpe Memorial Hospital as resident emergency surgeon. There he met his wife, Doreen, a ward sister. They married in 1951 and moved to Dukinfield, where they worked together in singlehanded general practice until he retired in 1985 . He leaves Doreen; four children; and seven grandchildren. [Julie Procter]

Longer versions of these obituaries are available on bmj.com 